\title{
The Olynthus mill in the Alps: New hypotheses from two unidentified millstones discovered in Veneto region (Italy)
}

\author{
Denis Francisci \\ Department of Cultural Heritage, University of Padua, Italy. Email: denis.francisci@gmail.com
}

\begin{abstract}
:
The archaeological collection at the Museum of Feltre (province of Belluno, Veneto region, Italy) includes fragments of two ancient millstones of type known as "Olynthus mill" or "hopper rubber". The first one (from San Donato, in the municipality of Lamón) is mentioned in a number of published and unpublished works; the other (generally from Feltre) is new to archaeological literature. Until now, they had never been identified as specimens of the Olynthus mill.

Following a brief introduction on this type of device (its technical features, origin and geographic distribution) and the main hypotheses concerning its diffusion in the Alps, the first part of this paper describes the two stones from Feltre: their dimensions, morphological features, raw material, etc. Consequently, this article will focus on the topographical areas where the stones were found and on their importance for understanding the diffusion of the Olynthus mill model in the Alpine region characterised by Raetic culture, which is still an unresolved problem. The sites of discovery of the two Olynthus mills (along with the places of origin of the other hopper rubbers found in the Veneto region and in the eastern part of the province of Trento) could suggest new working hypotheses about the provenance of this type of millstone and its introduction into the Raetic territory between $5^{\text {th }}$ and $4^{\text {th }}$ century BCE. More specifically, the Olynthus mill model might have been introduced into the Alps through the Piave and Brenta valleys and not the Adige valley as previously thought; the Olynthiantype mills from the Veneto region could therefore mark the stages of this south-north path rather than being mere outlying specimens of the Raetic area, or items exported from there.
\end{abstract}

Keywords: Olynthus mill; hopper rubber; prehistoric millstones; Raetic; Late Iron Age; Veneto region

\section{Introduction}

The fragments of two non-rotatory millstones are kept in the archaeological collection of the Museum of Feltre (province of Belluno) in the Veneto region, northern Italy (see Figure 1). Although only half of these artefacts have been preserved, they are clearly identifiable as the upper parts of two so-called "Olynthus mills".

\subsection{The Olynthus mill: a general overview}

The topic of "Olynthus mill" or "hopper rubber" has had plenty of coverage in archaeological literature (for a summary, see Alonso \& Frankel 2017; Peacock 2013: 38-53).

Published by the School of History, Classics and Archaeology, University of Edinburgh ISSN: 2055-0472. URL: http://journals.ed.ac.uk/lithicstudies/ 
This grinding device was composed of a fixed lower stone with a flat top surface and a mobile upper stone with a hopper in the middle. This hopper ended up in a slit in the lower side of the stone. From this slot, the grain placed in the hopper entered the space between the two stones, where they were ground by the motion of the upper stone.
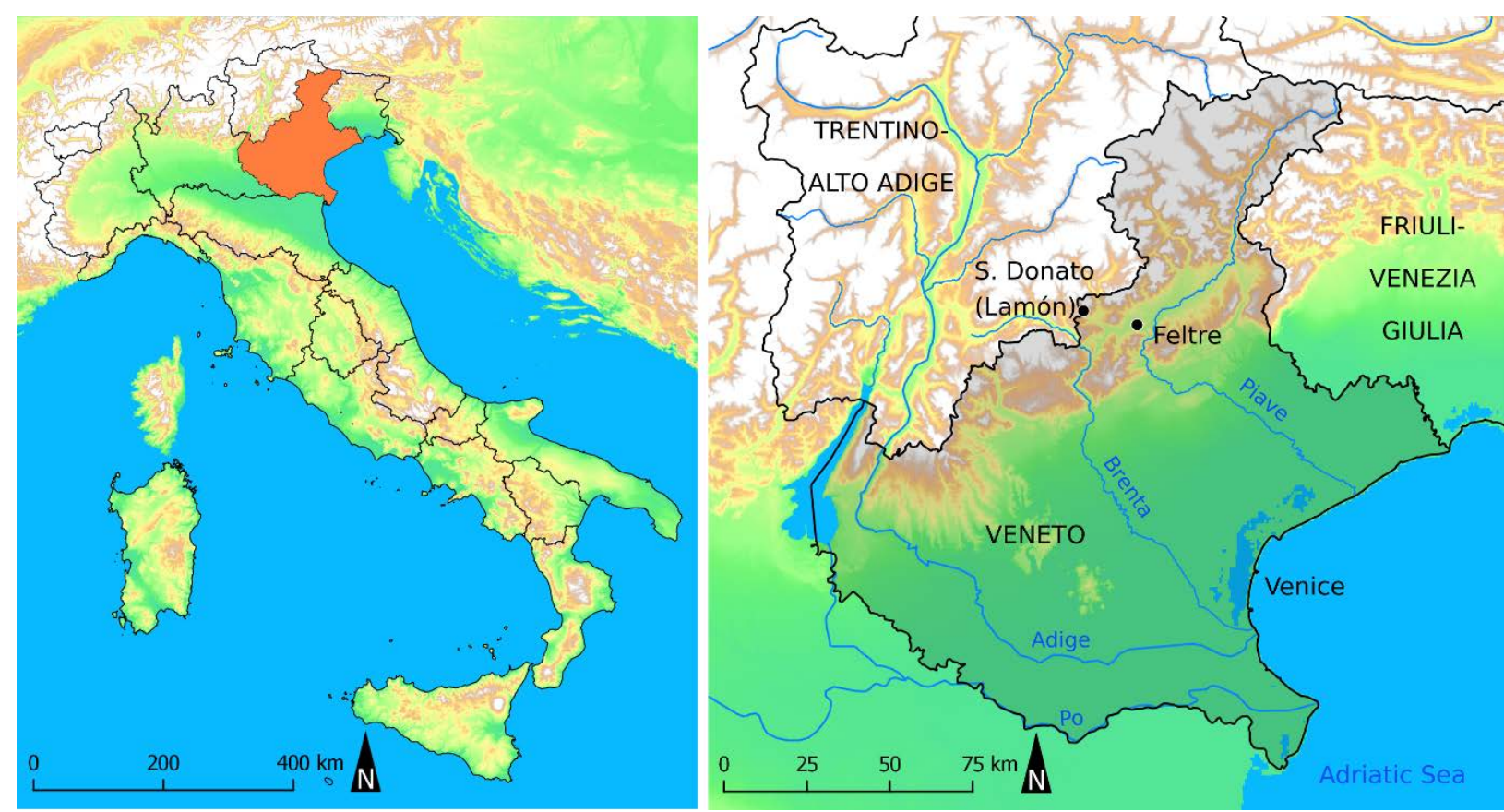

Figure 1. Veneto region in northern Italy.

This was moved by a wooden bar placed across the top of the stone in two rectangular slots cut on two opposite sides of the hopper's rim. Frequently, this rod was fixed to the stone with metallic hooks inserted in two small hollows carved directly below the two rectangular slots in the lower edge of the stone. Through this handle, the upper stone could be pushed toand-fro or operated in an oscillating mode: in the latter case, one end of the wooden beam was fixed to a pivot, while the other end served as a lever pushed and pulled to move the stone in an arc of circle (see Figure 2).

Sometimes, the working surfaces of the two stones had striation patterns in order to improve the grinding capacity and to facilitate the flow of the corn and the exit of the flour.

The shape of the stones and striation patterns had numerous variants depending on the geographic regions (Frankel 2003), but the general scheme and working technology were always the same.

The Olynthus mill appears to have been invented in the eastern Mediterranean. It had surely spread around Greece and, from here, across all regions where Greek settlements were present, such as Sicily, southern Italy (Magna Graecia), the south of France, Egypt, the Levant, the northern coast of the Black Sea, and up to the furthest border of the Empire of Alexander the Great in Afghanistan. From these areas, the model then spread in to non-Greek regions to the north, towards central and northern Europe: Romania, Serbia, Slovakia, the Czech Republic, Poland, Germany, etc. (see Figure 3).

Large amounts of specimens are to be found in the Alps, mainly concentrated in the modern-day Italian region of Trentino-Alto Adige. During the Late Iron Age $\left(5^{\text {th }}-1^{\text {st }}\right.$ cent. BCE) this region was part of the territory inhabited by the Raetic people (the so-called "Fritzens-Sanzeno culture") and this type of mill became one of the most common artefacts in the Raetic sites between $4^{\text {th }}$ and $2^{\text {nd }}$ century BCE. 

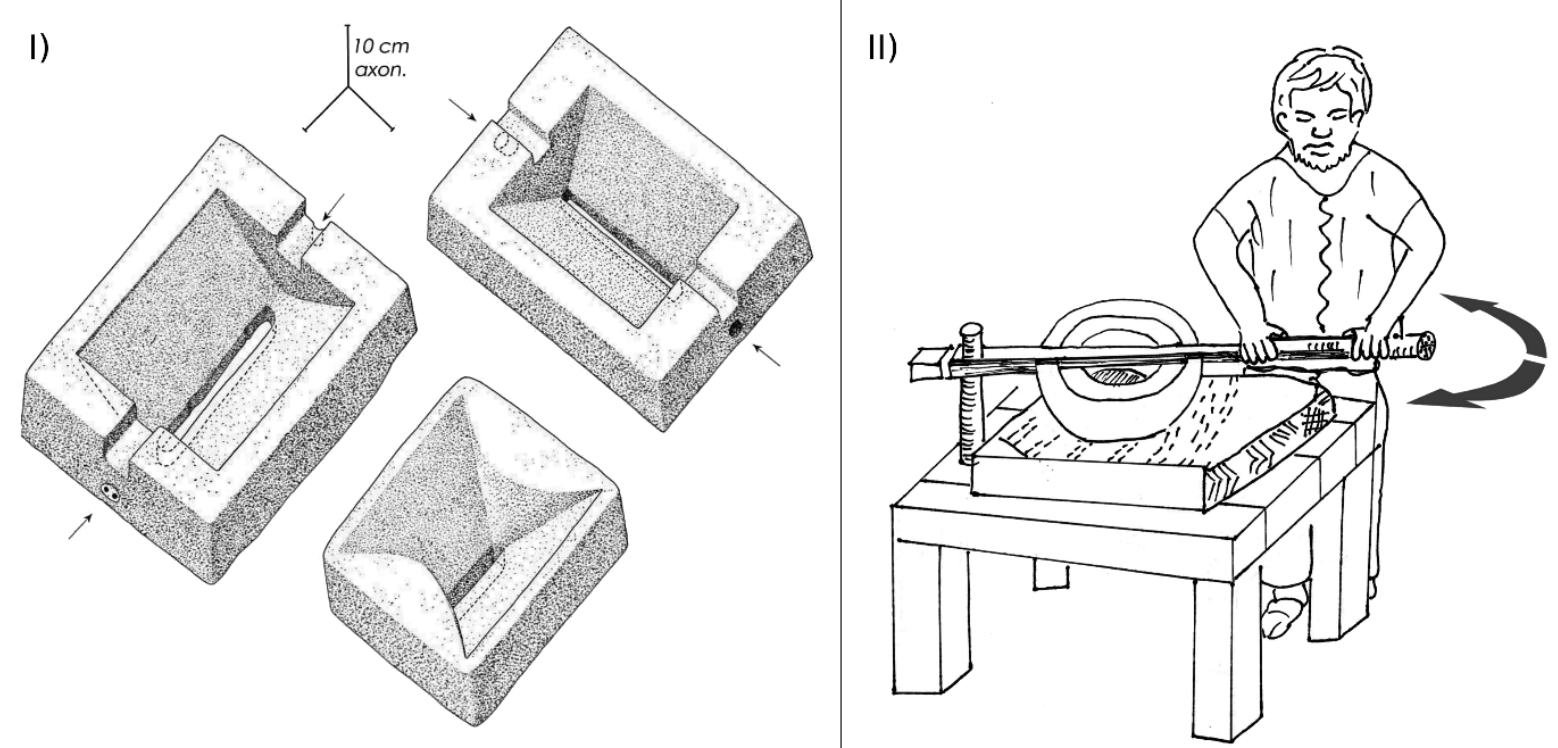

Figure 2. The Olynthus Mill. I) Samples of rectangular Olynthus mills (after Peacock 2013: 40); II) Operation of an "irregular" Olynthus mill with lever and pivot (after Francisci 2011: 14).

\subsection{The origin of Olynthus mill in the Alps: current hypotheses}

How the Olynthus mill model got to the Alps is still an unresolved problem. In fact, this type of instrument seems to be concentrated in the Raetic territory corresponding to the modern Trentino-Alto Adige region and its immediate surroundings, but it is almost completely absent in the neighbouring territories such as Austria, Switzerland, northwest and central Italy. The distribution area looks like an "island" with no connections to the other regions where Olynthus mills abound, such as the Greek colonies (Frankel 2003: 18).

Until recently, the prevalent assumption was that the Olynthus mill was brought to the Alps by the Etruscans. Between the $6^{\text {th }}$ and $4^{\text {th }}$ century BCE they had a strong influence on the Alpine people by importing objects, production methods and cultural models from the Italian peninsula, and played the role of the intermediary between the Alpine people and the Greek world (Dal Ri 1987; Marzatico 1999). The technology of the Olynthus mills is said to have come to the Etruscan trading centres of Spina or Adria at the northern Adriatic coast, either from the Greek colonies of southern Italy through the tyrrhenian Etruria or directly from Greece through the Adriatic Sea. From here, this device model (copied and modified) would have then reached the Alps by going up the rivers Po, Mincio, Adige and its tributaries (Dal Ri 1987: 166-170; 1992: 82-83).

This scenario seems very likely and many scholars have supported it (e.g., Morrone 1999: 76; Sassatelli 1993: 210-211; 1999: 470). Nevertheless, if it was the Etruscans who spread this new technology, the lack of Olynthus mills in their settlements is hard to explain (Alonso \& Frankel 2017: 478). The isolated cases of Monte Bibele (Morrone 1999) and Spina (Desantis 1998) are not enough evidence to support the widespread adoption of this type of instruments by the Etruscan people. The millstones from Monte Bibele (finished or semifinished) were imported from Latium; the Spina specimen, which was reused as part of a gravestone, was made of Aegean andesite and probably came from the ballast of a Greek ship. 


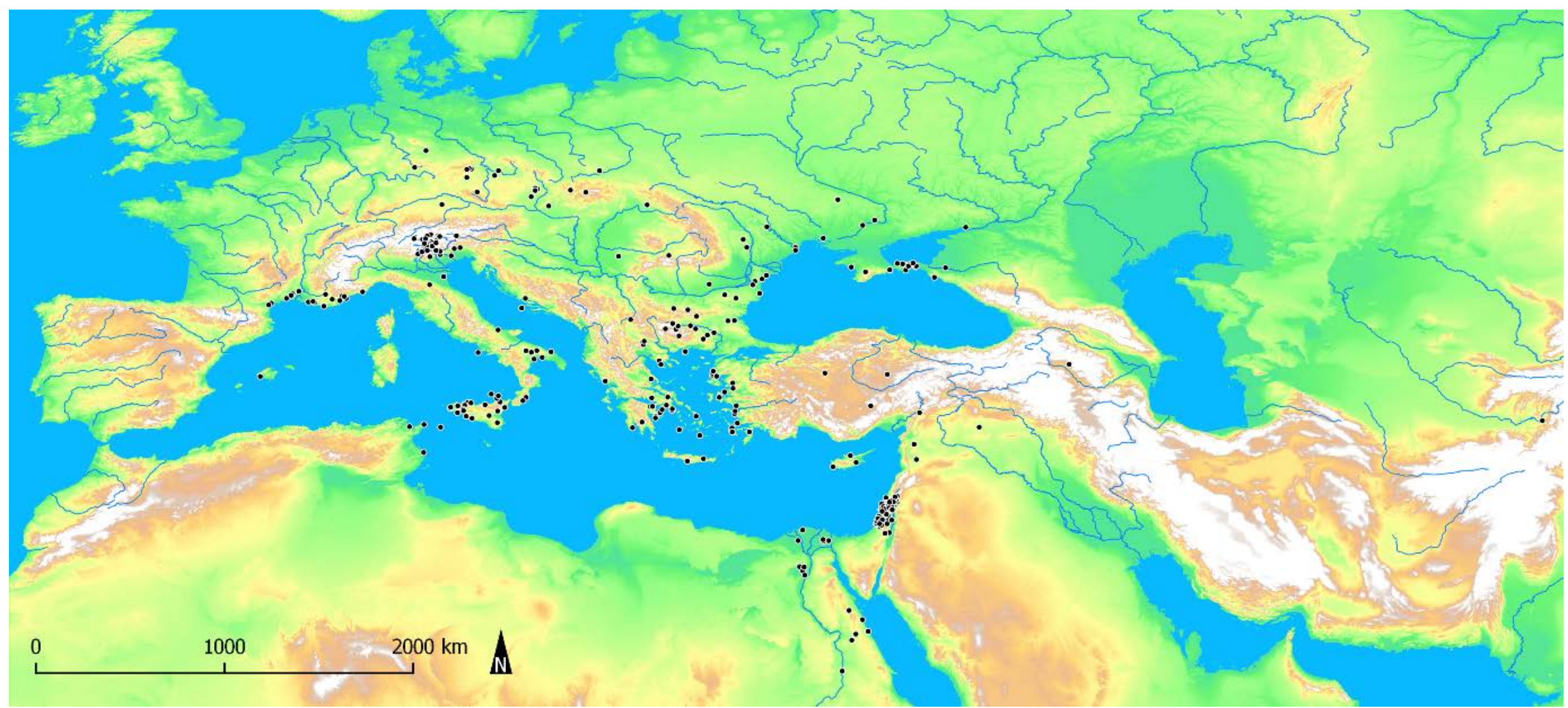

Figure 3. Distribution map with more than 300 Olynthus mill discovery sites (see Francisci 2017 and Figures 10-13 with related list of sites in supplementary files). 
An alternative way for the Olynthus mills to get to the Alps is by the Balkan (or Danubian) way (Lunz 1976: 58). According to this hypothesis, the Greek model would have been imitated in northern Greece and in Thrace, becoming rougher than the original: the stones did not come from quarries but were chosen among erratic boulders, and the shape always becomes more irregular compared to the rectangular shape of the Greek samples (Ivanova 2015). From Thrace (more or less modern Bulgaria) this “corrupt” model would have spread north along the Danube river or through the Balkans reaching central Europe (Romania, Slovakia, the Czech Republic, Germany) and then, from there, to the Alpine region.

Indeed, the shape and raw materials of the Raetic Olynthus mills are more akin to those of the Balkan specimens rather than the Greek or Etruscan (Monte Bibele and Spina) hopper rubbers, which were rectangular and produced in a quarry. On the other hand, the morphology of Balkan millstones is rougher and more deteriorated than the Alpine ones, as Dal Ri (1987: 169) has already highlighted; therefore, if there was any influence of one on the other, it is more likely that the Balkan Olynthus mills originated from the Raetic ones rather than vice versa (see below).

Along with the Etruscan and Balkan ways, the new Feltre millstones can perhaps suggest a third way.

\section{The Olynthus mills in the Museum of Feltre}

Until now, the two stones from the Museum of Feltre have not been identified as parts of two Olynthian-type mills. One of them comes from San Donato in the municipality of Lamón and it has already been mentioned by several scholars without defining the specific typology (Bersaglio 1971; Gaggia 1934; De Pantz 1892. They are the sources followed in more recent works: Capuis et al. 1988: 82, n. 2.2; Conte 2003: 12; Donner 1992: n. 55; Francisci 2018; Galifi 1998: 149). The second millstone has not been published yet and its origin is unknown.

Both are made out of granite; it could be argued that in their original form (i.e., before they were broken), the stones had a sub-circular (or ovoid) plan and a curved (or domeshaped) top surface. The raw material and shape are typical of most of the Olynthus mills from northern Italy.

These instruments were not a quarry product, but artefacts obtained from erratic boulders of igneous rock. These boulders, carried by glaciers and left in glacial valleys or in morainic contexts, were perfect for becoming millstones thanks to their "flatiron" shape and their lithological features. In fact, they have a high dome-shaped upper surface and a flat lower surface: the former allowed carving the hopper in the middle, and the latter was suitable for grinding. This shape is almost ready to use and does not require much processing in order to become a finished product. Furthermore, granite is very hard, wear-resistant, and compact, to avoid contaminating the flour, and rough enough to ensure good grinding.

\subsection{The Olynthus mill from San Donato (Lamón)}

The stone from San Donato in the municipality of Lamón (just a few kilometres west of Feltre) is broken into two parts: the larger one labelled as "M86" and the smaller as "M90". The two fragments combined form half of the upper stone of an Olynthus mill (see Figure 4).

As explained by the sources mentioning it, the stone was snapped into two by the person who discovered it in order to reuse the pieces of rocks to build a wall (Bersaglio 1971: 31). Shortly thereafter, the fragments were recovered by Pietro Tiziani (one of the first amateur scholars of local antiquities) and were brought to the Museum of Feltre at the beginning of the $20^{\text {th }}$ century. In the following decades, another piece of rock is likely to have been broken off: indeed, the old descriptions and drawing of this millstone (see below) confirm that the two 
fragments matched perfectly, while the outer part of the edge of the largest fragment is now missing, and there is a gap on the external side of the millstone.
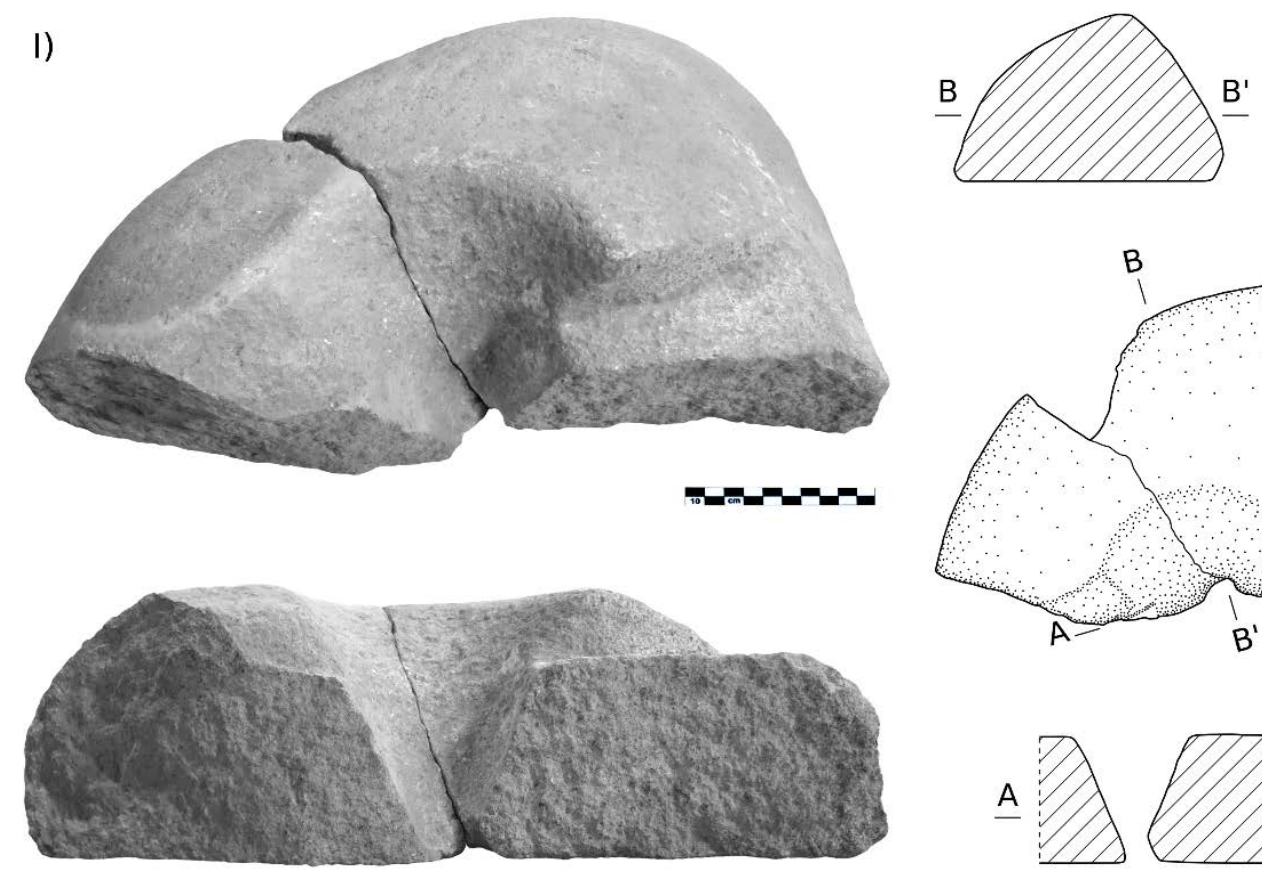

II)
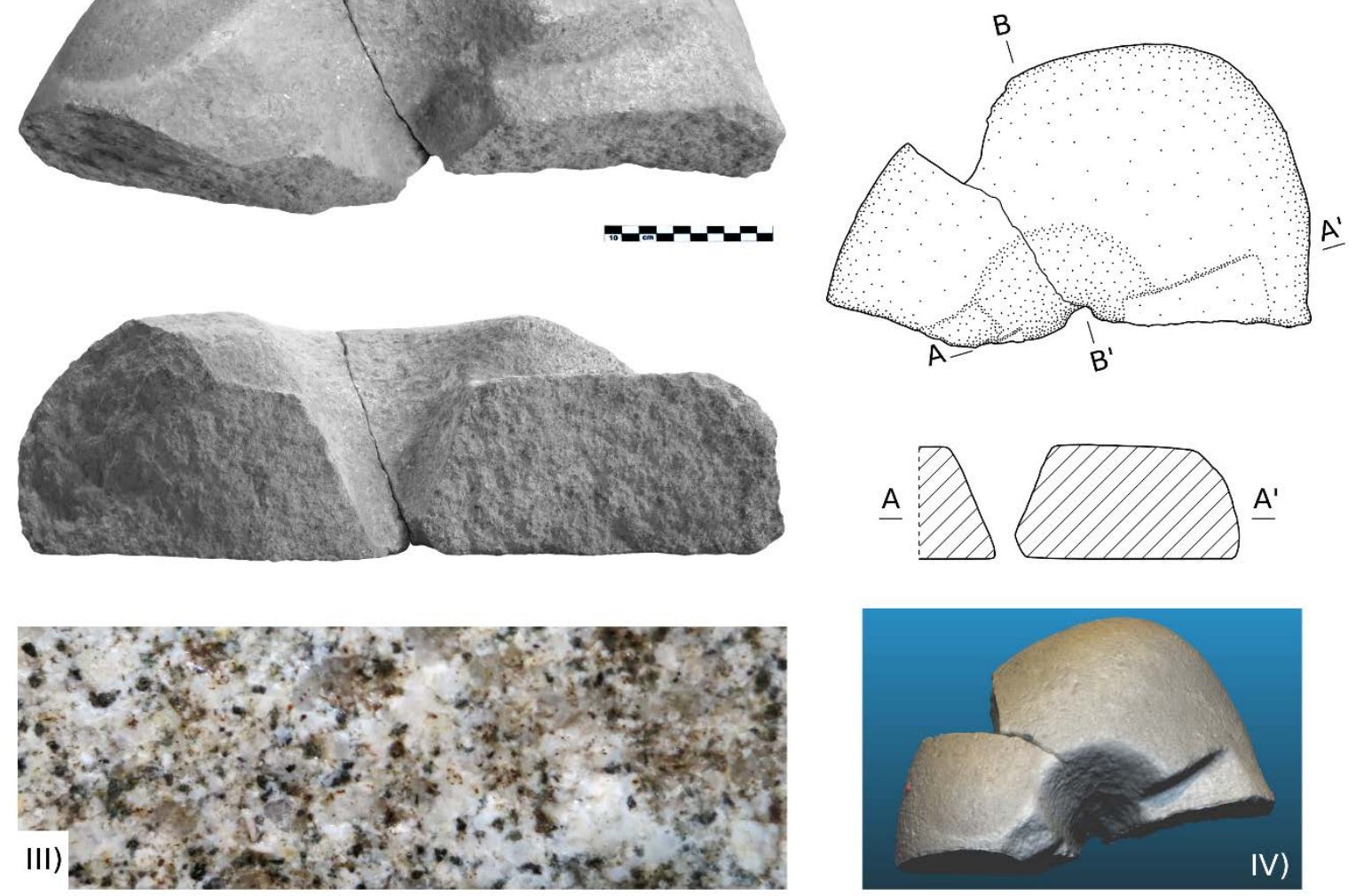

Figure 4. The Olynthus mill from San Donato (municipality of Lamón). I) Pictures (Courtesy of the Ministry of Cultural Heritage and Activities and Tourism; all rights reserved); II) Plan and section drawings; III) Detail of the granite; IV) 3D model (according to the method described in my post: Francisci 2017a).

The maximum dimensions of the combined fragments are $45 \mathrm{~cm}$ in length, $28.5 \mathrm{~cm}$ in width and $15 \mathrm{~cm}$ in height: the original maximum size should therefore be $45 \mathrm{x}$ circa 50 to 60 $\mathrm{cm}$.

There is a hopper in the middle of the original stone. The top edge has a circular shape with a diameter of $16.5 \mathrm{~cm}$. The vertical profile seems to have an "hourglass" shape: an inverted truncated cone, $13 \mathrm{~cm}$ deep, ends up in a narrow circular slit (diameter $0.7 \mathrm{~cm}$ ), that is in turn the top base of another small truncated cone (height $2 \mathrm{~cm}$; bottom base diameter 1.5 $\mathrm{cm}$ ). This second truncated cone is probably what is left of a circular (or elliptical) slit, which allowed grain to pass through. The hopper angle is circa $22^{\circ}$ from the vertical axis.

Two slots were carved at the opposite sides of the top edge of the hopper: they were used for inserting the wooden lever along the shortest axis of the stone. Only one of these slots is partly preserved: it has a rectangular section with a vertical edge of $4 \mathrm{~cm}$ and the horizontal one 2.5 to $6 \mathrm{~cm}$ wide. The opposite slot has been almost completely lost: the remaining part is circa $2.5 \times 1 \mathrm{~cm}$ at the edge of the hopper.

Beneath the rectangular slots there is no evidence of holes or notches used for hooking the lever to the stone. Many Olynthus mills had no hooking holes (sometimes, they did not even have slots), but the lever could be either free or fixed to the stone with other devices 
such as two vertical wooden rods attached to the lever, but only leaned against the outer edges of the top stone so that the handle was blocked (Frankel 2003: 11-13; Peacock 2013: 41-43).

The lower surface is perfectly flat and has no striations: the natural roughness of the granite was sufficient for optimal grain grinding.

The edges of the oldest breaks (not those of the end of $19^{\text {th }}$ century and subsequent) are sharp: it can thus be assumed that the stone was not left exposed to weather conditions for a considerable amount of time, but it was reused or buried soon after it was broken.

\subsection{The Olynthus mill of unknown provenance.}

The second millstone analysed is the upper part of an Olynthus mill. The remaining portion corresponds approximately to half of its original volume (see Figure 5).
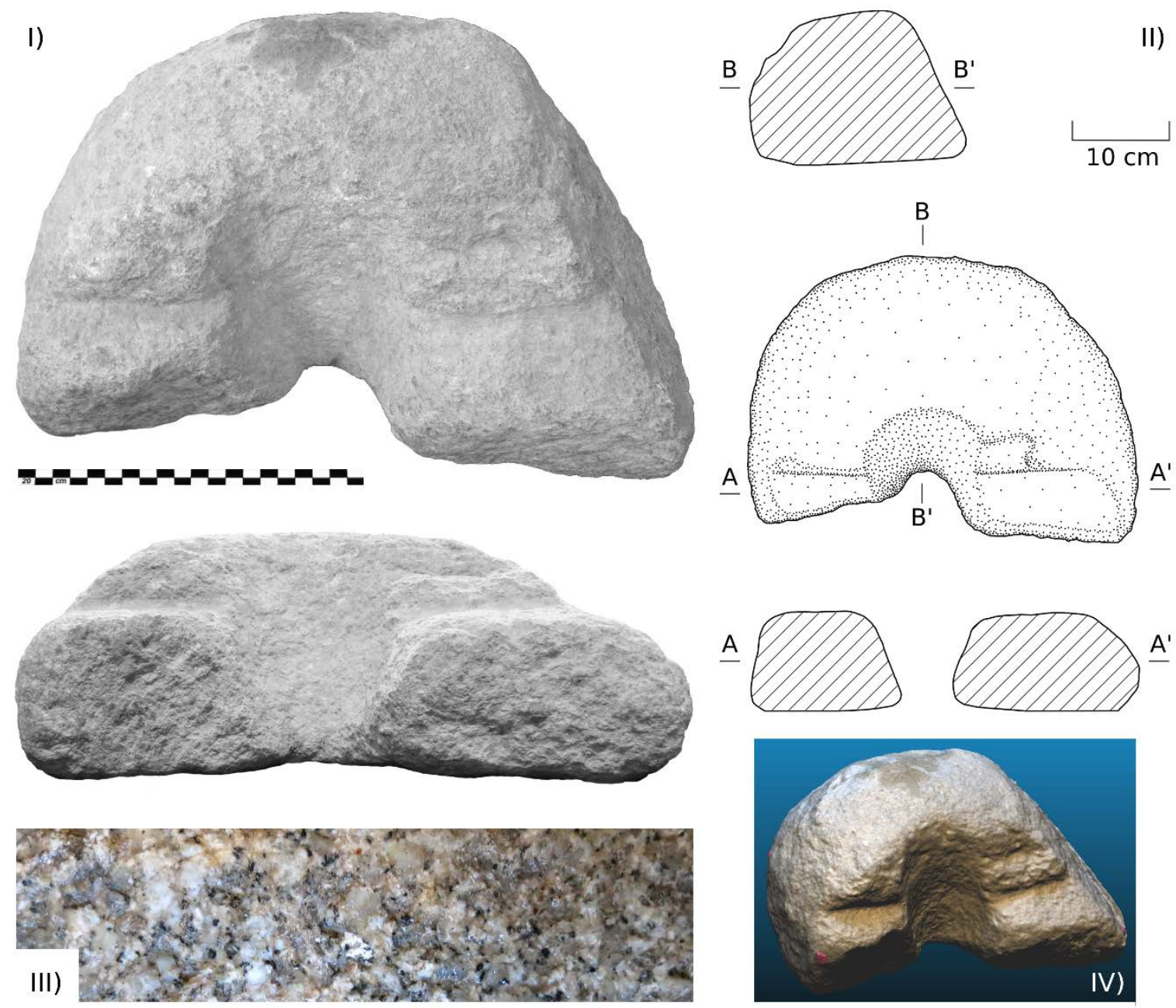

Figure 5. The Olynthus mill of unknown origin. I) Pictures (Courtesy of the Ministry of Cultural Heritage and Activities and Tourism; all rights reserved); II) Plan and section drawings; III) Detail of the granite; IV) 3D model.

The maximum dimensions of the preserved part are $40 \mathrm{~cm}$ in length, $30 \mathrm{~cm}$ in width and $16 \mathrm{~cm}$ in height: the original maximum size was $40 \mathrm{x}$ circa 50 to $60 \mathrm{~cm}$.

A hopper was carved in the middle of the stone and had an inverted truncated cone shape. The maximum diameter calculated from the remaining part is circa $12 \mathrm{~cm}$. The hopper probably ended with an ellipsoidal slit: at present, it is cut in half and the only measurable axis (the minor one) is circa $6.5 \mathrm{~cm}$. The hopper angle is $21^{\circ}$ to $25^{\circ}$ from the vertical axis. 
Along the short axis of the stone, two deep slots for the lever are cut on the top surface at the opposite sides of the hopper. These slots, only partly maintained, have a rectangular section with the vertical edges of circa $5 \mathrm{~cm}$ high (between 6 and 6.5 from the top of the stone) and the horizontal one $5.5 \mathrm{~cm}$ wide at its most preserved point.

As is the case for the previous sample, there are no hooking holes or notches under the rectangular slots. The lower surface is free of striations and almost completely flat, even if it has a very slight concavity towards the middle: this shape could facilitate the ingress of grain between the stones or could be caused by the ordinary consumption of the rock during the grinding process.

The rounded corners and edges are likely to be the result of prolonged exposure to natural weather conditions. There are no signs of human reuse such as re-workings or deposits of mortar (just some thin spots of lime on the lower surface might be traces of mortar, but only chemical analysis could confirm this assumption). The dark spots, both on the upper and lower surface, may be caused by contact with some artificial substance, which is currently not identified; on the contrary, the slight chip above the most preserved slot could be from natural damage.

\section{The discovery sites}

We know precisely the date and site of discovery of the first of the two Olynthus mills, as this was the millstone described in a manuscript written in 1900 by the aforementioned Pietro Tiziani (Tiziani 1900). He reported that Mr. Antonio Cengia found a fragment of an ancient millstone in September 1891 in San Donato (municipality of Lamón). The site of discovery was a field in a place called "Menotti" very close to the "Piasentoti" site, where recent excavations have unearthed a great Roman imperial cemetery (D’Incà \& Rigoni 2016).

The precise description of the artefact, the measurements registered and the drawing made by Tiziani (see Figure 6) perfectly match the millstone in the Museum of Feltre (except for the aforementioned loss of the outer part of the greatest fragment, after 1900). Tiziani even states that the millstone was found two meters deep, together with charcoal and two Roman coins: one perhaps of Augustus (27 BCE-14 CE) and the other one of Gordian (238-244 CE).
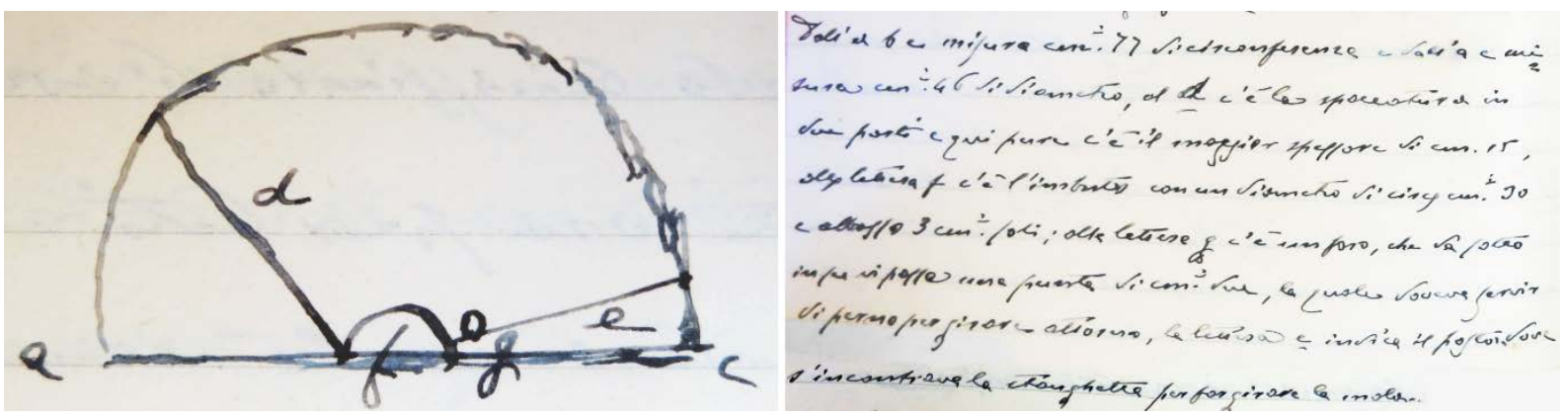

Figure 6. Original drawing and description of the Olynthus mill from San Donato in Tiziani's manuscript (Tiziani 1900: 20).

A second independent source, which preceded Tiziani's manuscript, reports the same, adding additional precious details. Indeed, De Pantz (1892) quotes the same date (September 1891), author (Antonio Cengia) and site of discovery (that he names "Crosère"), provides similar dimensions for the millstone (44 cm in length; 14 in height), but adds that it was found near an inhumation burial. The grave containing a skeleton with the coin of Gordian in its mouth was made of simple stones, fixed vertically in the earth. Even a manuscript from the parish archive of San Donato, reported by Bersaglio (1971: 30-31), provides similar details about the burial context. 
This information testifies that the mill wasn't in its original context, but it was probably reused in the building of the tomb. The primary context could be a Late Iron Age settlement in San Donato or nearby, but there have been no signs of this until now: the closest Late Iron Age settlement is Castel Tesino in the province of Trento (see below).

Finally, the reuse of the stone as well as its burial two meters underground explain the aforementioned sharpness of the broken edges.

As previously said, the site where the second Olynthus mill was found is unknown. The paper-registers of the findings that were brought to the Museum of Feltre since it was established (1903) record some ancient millstones, but the paucity of descriptions and the complete absence of inventory numbers, drawings and, obviously, pictures do not allow linking the object of our interest to any one of the discovery sites listed in the aforementioned registers.

Nevertheless, it is almost entirely certain that this fragment of an Olynthus mill comes from Feltre or its nearest countryside. In fact, a deep study of the museum registers has shown that the place of provenance can only be one of the streets of Feltre, where excavations and findings of millstones were made between 1903 and 1910: "via del Paradiso", "via G. Garibaldi” (Museum Register 1903) or "via M. Tomatico” (Museum Register 1929). Among these locations, it is slightly more probable that the millstone is the one from via del Paradiso which was found in a courtyard and not underground: this open location fits very well with the smooth corners and broken edges.

It is also possible (although highly unlikely) that the stone arrived at the Museum with no registration; but here, too, the place of its origin must be not too far from Feltre. In fact, a broken piece of mill cannot be considered as a collector's item, sold or bought by antiques dealers. It is therefore hard to imagine that it comes from afar, through the antique trades in the same way as statues or reliefs; at most, it might have been part of a private collection of a local amateur that gathered ancient objects found nearby and then decided to give them to the museum.

Feltre, moreover, is a very appropriate context for this type of object. As previously mentioned, the Olyntus mill is typical of the Raetic culture in the Alpine region. During the Late Iron Age, Feltre and its countryside were certainly Raetic territories as shown by the discovery of Raetic houses in the city centre, by the inscriptions in Raetic alphabet and by the words of Pliny the Elder that record Feltre among the "raetica oppida" (Nascimbene 2009: 21-22; Pliny the Elder 77-79, vol. 3: 130; Rigoni \& Maggiani 2002).

Assuming that the two millstones come respectively from San Donato (or nearby) and Feltre (or its countryside), the sites of discovery become more interesting than the typological and technical features common to this type of instrument. In fact, these two specimens not only increase the small number of Olynthus mills in the Veneto region (where saddle querns were the common grinding tools until the introduction of rotatory millstones at the beginning of the Roman Age; see Donner 1995), but they also allow to evaluate them all from a topographic point of view.

Until now, four Olynthus mills have been found in the Veneto region (Donner 1995: 395396). Excluding the Santorso sample which is in the province of Vicenza, the other three Olynthian-type mills come from sites located in (or linked to) the valley and alluvial plain of the Piave river (hereafter "Piave valley"): one from Oderzo (the ancient Opitergium in the province of Treviso) and two from Castelciés (municipality of Cavaso del Tomba, province of Belluno).

The millstones from San Donato and Feltre are also in proximity of the Piave valley. More precisely, they lie on the line linking the Piave valley and the Brenta valley in TrentinoAlto Adige region. 
Scholars have considered the Olynthus mills from Veneto to be the result of influences coming from the Trentino-Alto Adige region (where the Olynthus mills are especially numerous), and moving to the periphery of the Raetic area, as are the cases for Castelciés or Santorso, or to the Venetian cities, as is the case for Oderzo (Donner 1995: 396). These mills could be commercial products made in Trentino-Alto Adige and exported to Veneto, artefacts made locally by Raetic artisans coming from the central Alps, or by local workers using models and technologies developed further north. Alternatively, they could belong to Raetic persons that carried the precious device when moving from Trentino-Alto Adige to Veneto. Indeed, an Olynthus mill had to be an expensive item, its manufacture was time consuming and required specific knowledge and skills in choosing the most suitable raw material, and in carving the hopper and the other components of the device.

Based on this hypothesis, the new millstones from the Museum of Feltre are important as they show the path along which these influences run, i.e., from Trentino-Alto Adige to the Veneto plain through the Brenta and Piave valleys.

This is still the most likely hypothesis about the circulation of Olynthus mills in northern Italy. However, the location of the millstones from San Donato and Feltre could open new possibilities: instead of considering the Brenta-Piave road system as the way for Olynthus mills to be exported from the Alpine region to the Veneto plain, this linking path could be seen as the way for the Olynthus mill model into the Alps. In other words, the Olynthus mills from the Museum of Feltre, along with the others from the Veneto region, could mark a south to north path, which may have carried this type of instrument from the Veneto plain into the Alps through the Piave and Brenta valleys (see Figure 7).

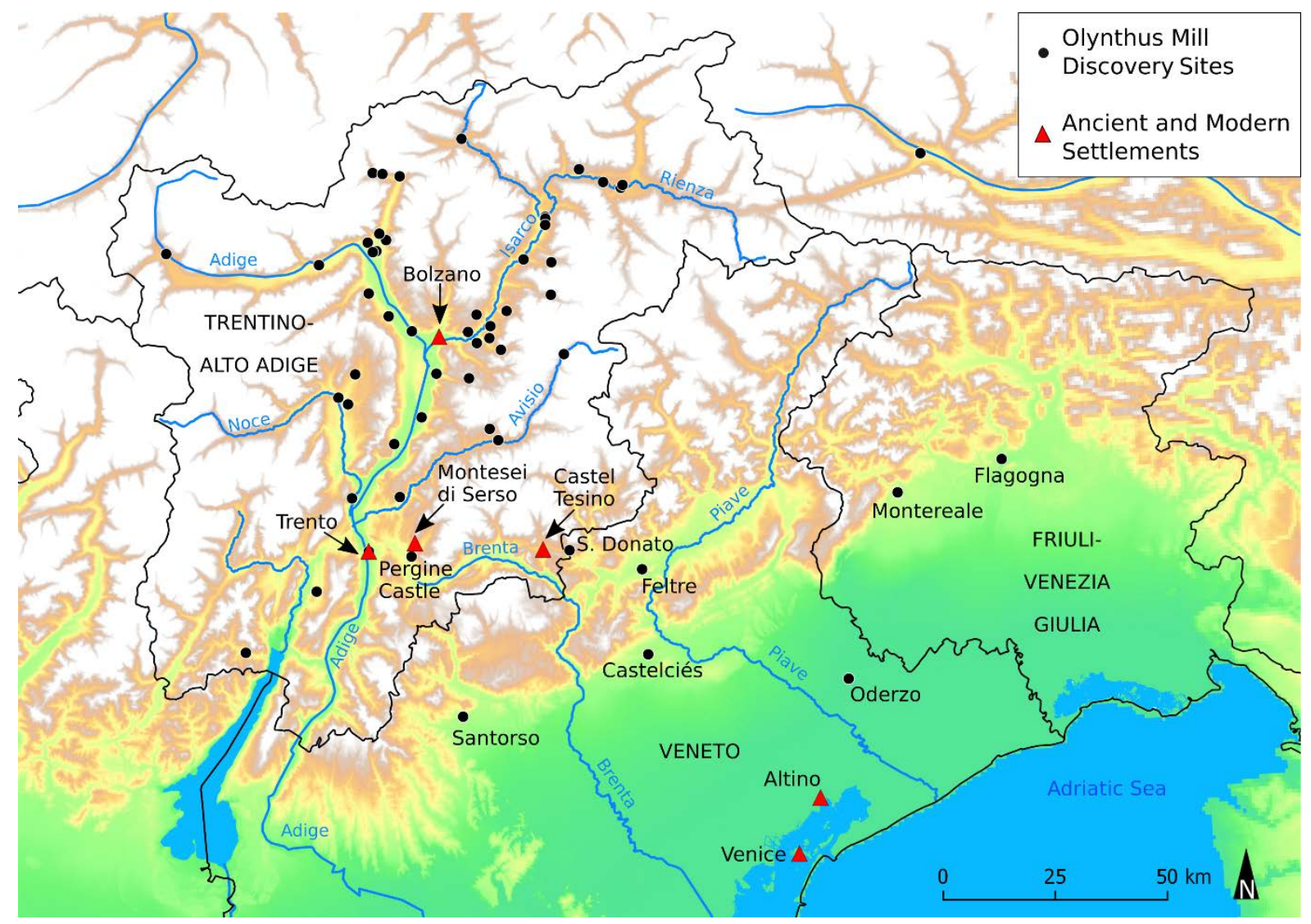

Figure 7. Olynthus mill discovery sites in northern Italy. 


\section{Towards a new hypothesis: the Piave-Brenta way}

The findings of Greek objects, in particular Attic pottery, in the main pre-Roman centres of the Veneto region (Padua, Este, Altino, etc.) are numerous. These fragments might have come from the aforementioned trade centres of Spina and Adria through Etruscan intermediaries or thanks to Greek merchants who directly landed on the northern coast of Veneto (Braccesi \& Veronese 2013a; 2013b).

Even the Greek technology of the Olynthus mill might have reached the Veneto region through the same routes: either from the Adriatic Etruscan centres through the Venetian lagoon waterways, or from Greece or the Greek colonies of Sicily, southern Italy and eastern Adriatic coast aboard the merchant vessels going up the Adriatic Sea (Peacock 2013: 52) to the harbours of the Venetian lagoon, such as Altino.

From here, the mill model might have been introduced to some cities of the Veneto region, such as Oderzo. During an archaeological excavation in March 1980 in the centre of Oderzo, an Olynthus mill was found (Archive of Superintendence of Archeology, Fine Arts and Landscape for the City of Venice and Lagoon, Registro inventariale generale, IG 24608; Donner 1992: n. 84). Although it was not in its original context, the millstone could be a local replica of the Olynthus mill model which arrived to the city together with other Greek objects (even some sherds of Attic pottery were found in Oderzo: see Bonomi 1996). This device might have been made by a Greek craftsman working in Veneto or by a Venetian artisan imitating a Greek sample he had seen or heard about (see Figure 8, I).
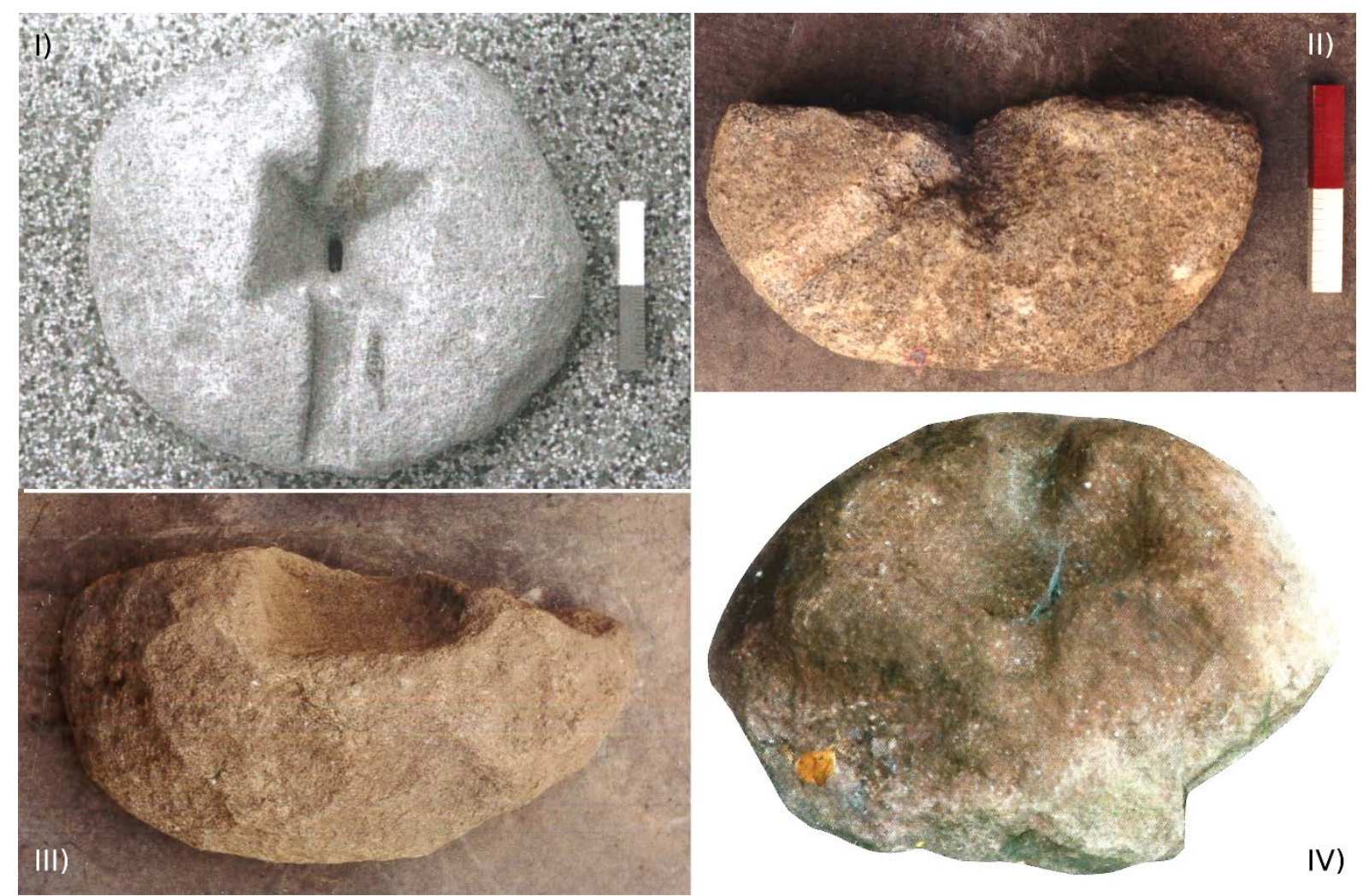

Figure 8. The other Olynthus mills from the Piave and Brenta valleys. I) Oderzo (after Donner 1992); II-III) Castelciés (after Donner 1992); IV Castle of Pergine (after Pasquali 2010: 101).

From the coast or from the main urban centres of the Veneto region, the mill model might have reached the Alps by going up the Piave river, either through Venetian intermediaries or directly thanks to the Raetic people. During the Late Iron Age, the Piave valley was a territory of contact between Venetian and Raetic people, and a hub for some 
important road paths from west to east (from Adige valley to Slovenia) and from south to north (from the Venetian plain to the Alps and northern Europe) (Gambacurta 1999; Marzatico 2013; 2014). It is therefore possible that the Olynthus mill model spread along this way, as the two specimens of Castelciés (see Figure 8, II-III.) would appear to show (Donner 1995; Rigoni 1990: 122; 2004: 53). San Martino of Castelciés was a pre-Roman site located in a commanding position on the Piave valley near the point where the river exits from the mountains and flows towards the plain. Some findings coming from there qualify it as a Raetic site: among them, a very important inscription in the Raetic alphabet dating back to the beginning of the $4^{\text {th }}$ century BCE (Morandi 1999). In the same site, some objects of the Venetic culture were found: they show the strong links between the Raetic people of Castelciés and the inhabitants of the Venetian plain (Rigoni 1990; 1991; 1993; 2004).

Going up the Piave river and turning slightly northwest, Feltre is reached. The Olynthus mill of unknown origin, but probably from Feltre or nearby, might indicate another stage of the south-north path, which carried this type of mill from the Venetian plain to the Alps through the Piave valley. Even in Feltre and its countryside both Raetic and Venetic evidences have been found (Capuis et al. 1988: 83-84, n. 13-14.1) which confirm the close relationship between this mountainous area and the Venetian plain centres, supporting the idea of a possible southern provenance of the Olynthus mill model.

From Feltre, this revolutionary grinding device would have moved towards TrentinoAlto Adige region passing through San Donato, as the Olynthus mill discovered here would seem to confirm. Although there is no evidence dating back to the Iron Age in this area so far (except for a fibula from the $6^{\text {th }}-5^{\text {th }}$ century BCE from Lamón: see Nascimbene 2009: 105, n. 37), there is however a well-known historical path that linked Feltre to the Brenta valley passing through Lamón and San Donato. On this road there was also the important Raetic settlement of Castel Tesino (in Trentino-Alto Adige region), a few kilometres west of San Donato (Bruschetti 1999). It is highly likely that the device model was passed through this way and these settlements, reaching the Brenta valley in Trentino-Alto Adige region and moving up the Brenta river towards the central Alps.

At the western end of the Brenta valley another Olynthian-type mill was found (Pasquali 2010: 97-101; Piatti 1998: 133; see Figure 8, IV.): this one came from the Castle of Pergine hill (or its surroundings) where there was probably an Iron Age settlement, which is very close to the important Raetic settlement of Montesei di Serso (Perini 1978). Once again, this millstone could mark the way travelled by the Olynthus mill model to get to the central Alps.

Once it had reached the high Brenta valley, the new technology might have spread northwards: along the valleys of the Avisio river, where numerous Olynthus mills were found (Dal Ri 1991); along the Adige, Isarco and Rienza valleys where the model seems to take root and the samples are widespread; in western Trentino where (excluding Val di Non) the Olynthus mills become rarer (see Figure 7).

Finally, this Raetic area might have been the starting point for the diffusion of the hopper rubber in to northern and central Europe. As previously mentioned, most of the Olynthus mills from Germany, the Czech Republic, Slovakia and Poland, appear to be rougher than the Raetic ones: they could be degraded copies of a model coming from the Alps. However, this is still not entirely certain: looking at the distribution map (see Figure 3), there is a great distance between the Alpine mills and the nearest Olynthus mill from central Europe. This could be due to research and knowledge gaps, but could also testify to the absence of a direct transfer from the Alps, and that they instead could have come from Thrace, the northern coast of the Black Sea or, as some scholars suggested, even from southern France (Šedo 2004: 912). Also, the Raetic and central Europe Olynthus mills could represent local and unrelated modifications of the Greek model. 
In addition to the millstones from the Piave-Brenta way and Trentino-Alto Adige region, there are also other Olynthus mills in northern Italy: the aforementioned specimen from Santorso in the province of Vicenza and others from Montereale Valcellina and Flagogna in the Friuli Venezia Giulia region (see Figure 7). Santorso belonged to the Raetic territory, inhabited by the so-called "Group of Magré"; Montereale and Flagogna are sites located at the foothills of the Alps and show strong Raetic influences, although they are quite far from the actual Raetic area (Marzatico 2013; 2014). According to the scenario described above, they could represent other ways, alternatives with respect to the Piave valley, through which the hopper rubber has spread from the Venetian plain to the Raetic Alps. The fact that the millstones from Montereale seem to be the most ancient in northern Italy ( $5^{\text {th }}$ century BCE) might support this hypothesis; nevertheless, it is also likely that these samples, placed at the periphery of the Raetic region, are to be seen as the furthest points of model diffusion among the Raetic people.

\section{Discussion and conclusions}

For now, the scenario described above represents just a working hypothesis mainly grounded in the geographical location of the new Olynthus mills from San Donato and Feltre and the other Venetian hopper rubbers. This idea is however an alternative to the more popular theory of the "Etruscan intermediary". The two assumptions share a common starting point for the diffusion of the Olynthus mill in the Raetic Alps, i.e., the trade centres of Adria and Spina, although a direct provenance from the Greek world is also possible.

If, according to the new hypothesis, the Etruscans indeed played the role of intermediaries between the Greek world and the Alpine region they did this only up to the Veneto area: from here, the Venetic or the same Raetic people probably replaced Etruscans in this function. Dal Ri (1987: 170) states that the Etruscans were the only ethnic and political entity able to play this role, but the economic and political level achieved by the Venetian cities in the Late Iron Age was not much smaller than the Etruscan one.

In addition to the different intermediaries, this new hypothesis also suggests different routes: instead of the Po, Mincio, Adige rivers, the Piave and Brenta valleys served as the routes. In this alternative scenario, the Olynthus mills further south of the Alpine region could be seen as markers of diffusion from south to north rather than outlying specimens of the Raetic region (see Figure 9).

However, this new theory is also difficult to confirm. All Venetian millstones considered here and most of the Alpine hopper rubbers from Trentino-Alto Adige region do not come from closed original contexts. This makes them impossible to date precisely and therefore it is difficult to understand if the geographical movement from south to north corresponds to a chronological progress from the oldest to the newest. Without a clear dating of the mills, it is hard to reconstruct the spread of the Olynthus technology in this region.

Furthermore, this type of mill was obtained by erratic boulders, which sometimes come from regions far away. It is therefore quite difficult to establish whether the rock the millstone was carved from had been carried by glaciers (the mill would be a local artefact) or brought by humans from afar (the mill would be an imported product). In this respect, even the petrochemical analyses (planned for the future) are not decisive: they could aid only if the millstones had been made of a lithotype that the glacier couldn't have carried as it was too far from the glacial flows of the region of interest. 


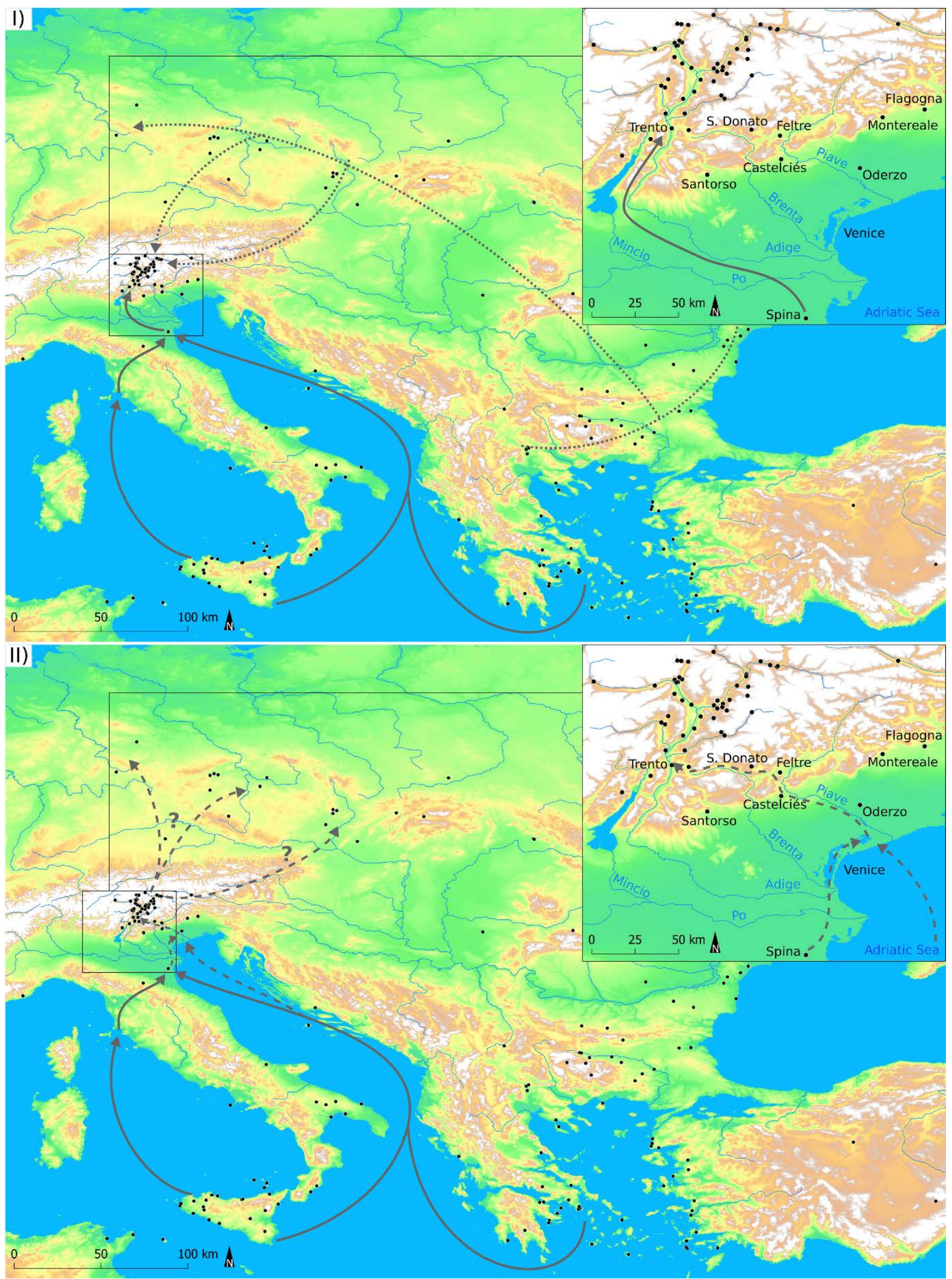

Figure 9. Olynthus mill in the Alps: old and new hypotheses. I) "Greek-Etruscan” way (continuous line) and "Balkan or Danubian” way (dotted line); II) Venetian "Piave-Brenta" way (dashed line).

A case like this could be the one from Oderzo, the only specimen from the Veneto region with a preliminary lithological classification. According to Donner (1995: 396) the raw material of the millstone from Oderzo should be "Granite from Bressanone" (province of 
Bolzano). If this is true, the grinding device could have been made in Alto Adige and exported to the Venetian plain. Nevertheless, the lithological definition is only based on a macroscopic analysis, which is not sufficient for a certain identification of the stone that could be a lithotype similar to, but not identical to the Granite from Bressanone (e.g., Granodiorite) or an erratic boulder transported by the glacier.

Without knowing the origin of the raw material, it is challenging to define possible import-export movements of finished or semi-finished products from one place to another. It is likely that in most cases the Alpine Olynthus mills were made with local raw material: rather than the stones, it was the models and artisans that moved around (as opposed to the Greek and then Roman world, where the millstones were traded even to faraway places) and these movements are difficult to map with archaeological tools.

Even if the hypothesis of the Piave-Brenta way was true, we are left with the question of why the Etruscans and Venetians did not use this new grinding technology. Only the Raetic people welcomed it unreservedly, and disseminated it so widely in their territory that the Olynthus mill can be considered as an "index fossil" for the Raetic culture: in fact, all the Venetian millstones, except the one from Oderzo, come from more or less peripheral Raetic territory.

We do not know the reason for these two different approaches to the hopper rubber by the populations of northern Italy. The availability of raw material in the Raetic territory could have played a part, i.e., the abundance of igneous rock boulders, which were easy to get in the riverbeds or in morainic deposits of the Alpine valleys, and rarer in the Venetian and Po plains. Naturally, it is a necessary but not sufficient condition to explain the phenomenon: in fact, igneous rocks in the form of erratic boulders are to be found even in the western Alps, but no Olynthus mill has been discovered there yet.

For now, the only certainty is that the Piave valley was travelled by the Olynthus mills either from south to north or vice versa. Once again, this confirms the importance of this path in the Late Iron Age. It was maintained in the Roman period too, when the branch of the via Claudia Augusta coming from Altino, as well as the road between Oderzo and Trento recorded by the Antonine Itinerary (It. Ant. 280, 5 - 281, 1), went through the Piave and Brenta valleys.

\section{Acknowledgements}

Marianna Bressan (Superintendence of Archeology, Fine Arts and Landscape for the City of Venice and Lagoon), Tiziana Casagrande (Museum of Feltre), Lorenzo Dal Ri, Chiara D'Incà (Superintendence of Archeology, Fine Arts and Landscape for the City of Venice and Lagoon), Maddalena Donner, and Mattia Valdegamberi.

\section{References}

Alonso, N., \& Frankel, R. 2017, A survey of ancient milling systems in the Mediterranean. Revue Archéologique de l'Est (RAE), 43 (Supplément): 461-478.

URL: http://hdl.handle.net/10459.1/63088

Bersaglio, B. 1971, Tra il monte e la valle. Notizie storiche di San Donato di Lamon.

Tipografia Piave, Belluno, 158 p. (in Italian) ("Between the Mountain and the Valley. Historical Information about San Donato in the Municipality of Lamon”)

Bonomi, S. 1996, Ceramica attica. In: La protostoria tra Sile e Tagliamento. Antiche genti tra Veneto e Friuli, Esedra, Padova: p. 111. (in Italian) (“Attic Pottery”) 
Braccesi, L., \& Veronese, F. 2013a, Padova prima di Padova. La città e l'universo veneto. Quaderni delle regaste Vol. 5. Cierre, Sommacampagna, Verona, 213 p. (in Italian) ("Padua before Padua. The City and the Veneto Universe")

Braccesi, L., \& Veronese, F. 2013b, Veneti e Greci. In: Venetkens. Viaggio nella terra dei Veneti antichi (Gamba, M., Gambacurta, G., Ruta Serafini, A., Tiné, V., \& Veronese, F., Eds.), Marsilio, Venice: p. 138-143. (in Italian) ("Venetians and Greek”)

Bruschetti, A. 1999, L'insediamento del Dosso di Sant'Ippolito a Castello Tesino. In: I Reti/DieRäter. Atti del Simposio (September 23-25 1993, Castello di Stenico, Trento), Vol. 2 (Ciurletti, G., \& Marzatico, F., Eds.), Archeologia delle Alpi Vol. 5, Provincia Autonoma di Trento, Trento: p. 39-58. (in Italian) ("The Settlement of Saint Hippolyt Hill at Castello Tesino”)

Capuis, L., Leonardi, G., Pesavento Mattioli, S., \& Rosada, G., (Eds.) 1988, Carta archeologica del Veneto. Vol. 1. Panini, Modena, 321 p. (in Italian) (“Archaeological Map of the Veneto region”)

Conte, P. 2003, Lamon: profilo storico di una comunità di confine. Pro Loco di Lamon, Lamon, Belluno, 142 p. (in Italian) ("Lamon: Historical Background of a Border Comunity")

Desantis, P. 1998, Un problematico segnacolo tombale a Spina: la macina a tramoggia in andesite della tomba 15 C di Valle Pega. Archeologia dell'Emilia-Romagna, 2(1): 91100. (in Italian) (“A Problematic Grave Marker from Spina: the Andesite Hopper Rubber from Tomb 15 C of Valle Pega”)

Donner, M. 1992, Macine per cereali nel Veneto di età romana. Master’s thesis at the Department of Antiquity Sciences, University of Padua, Padua, 143 p. (in Italian) ("Grain Millstones in Veneto region in Roman Age")

Donner, M. 1995, La macina per cereali nel Veneto di età romana. In: Nel nome del pane. Atti del IV Colloquio Homo Edens: regimi, miti e pratiche dell'alimentazione nelle civiltà del Mediterraneo (June 3-6 1993, Bolzano) (Longo, O., \& Scarpi, P., Eds.), Regione Trentino-Alto Adige, Trento: p. 391-406. (in Italian) (“Grain Millstones in Veneto region in Roman Age")

Francisci, D. 2011, Macine per cereali dalla Val di Non. Dal manufatto alla storia. Quasar, Rome, 184 p. (in Italian) ("Grain Millstones from Val di Non. From the Artefact to History”)

Francisci, D. 2017, Olynthus Mill Distribution Map project. Retrieved 25 January 2019. URL: https://www.researchgate.net/project/Olynthus-Mill-Distribution-Map

Francisci, D. 2017a, 3D documentation of ancient millstones: preliminary tests. Retrieved 25 January 2019. URL: http://arc-team-open-research.blogspot.it/2017/09/3ddocumentation-of-ancient-millstones.html

Francisci, D. 2018, Macine e tombe dalla Preistoria all'alto Medioevo: due esempi alpini dalla Provincia di Trento. In: Memento mori. Ritualità, immagine e immaginario della morte nella Alpi (Giarelli, L. Ed.), Tricase, Lecce, p. 279-294. (in Italian) ("Millstones and Burials from Prehistory to Early Middle Age: Two Alpine Examples from the province of Trento”)

Frankel, R. 2003, The Olynthus Mill, Its Origin, and Diffusion: Typology and Distribution. American Journal of Archaeology, 107(1): 1-21. doi:10.3764/aja.107.1.1 
Gaggia, M. 1934, Traccie di romanità in San Donato di Lamon. Archivio Storico di Belluno, Feltre e Cadore, 6: 486-487. (in Italian) ("Signs of Roman Period in San Donato in the Municipality of Lamon”)

Galifi, C. 1998, Ritrovamenti monetali di età romana nel Veneto. Provincia di Belluno. Feltre. Vol. I/2. Esedra, Padova, 260 p. (in Italian) ("Roman Age Coin Findings from the Veneto region. Province of Belluno. Feltre”)

Gambacurta, G. 1999, Considerazioni sul ruolo della Valle del Piave: Aspetti culturali e cultuali. In: Protostoria e storia del "Venetorum Angulus". Atti del XX Convegno di studi etruschi ed italici (October 16-19 1996, Portogruaro-Quarto d'Altino-Este-Adria) (Paoletti, O., Ed.), Istituti editoriali e poligrafici internazionali, Pisa and Roma: p. 437452. (in Italian) ("Remarks about the Role of the Piave Valley: Cultural and Religious Aspects”)

D’Incà, C., \& Rigoni M., (Eds.) 2016, La necropoli romana di San Donato. Guida del Museo Civico Archeologico di Lamon. Edizioni DBS, Seren del Grappa, Belluno, 87 p. (in Italian) ("The Roman Cemetery of San Donato. Guidebook of the Archaeological Museum of Lamon”)

Ivanova, N. 2015, Grinding, Crushing, Worshipping. A case study of Olynthus mills in Late Iron Age Thrace. In: Olive Oil and Wine Production in Eastern Mediterranean during Antiquity. Proceedings of International Symposium (November 17-19 2011, Urla-İzmir) (Diler, A., Şenol, K., \& Aydinoğlu, Ü., Eds.), Ege Üniversitesi Edebiyat Fakültesi yayınları Vol. 189, Ege Üniversitesi, İzmir: p. 141-154.

Lunz, R. 1976, Urgeschichte des Raumes Algund Gratsch Tirol, Archäologisch-historische Forschungen in Tirol Vol. 1. Athesia, Bolzano, 127 p. (in German) ("Prehistory of Areas of Algund, Gratsch and Tirol”)

Marzatico, F. 1999, Apporti etrusco-italici nell'area retica. In: Protostoria e storia del "Venetorum Angulus". Atti del XX Convegno di studi etruschi ed italici (October 16-19 1996, Portogruaro-Quarto d'Altino-Este-Adria) (Paoletti, O., Ed.), Pisa-Roma: p. 475484. (in Italian) ("Etruscan-Italic Contributions in Raetic Area")

Marzatico, F. 2013, Veneti e Reti. In: Venetkens. Viaggio nella terra dei Veneti antichi (Gamba, M., Gambacurta, G., Ruta Serafini, A., Tiné, V., \& Veronese, F., Eds.), Marsilio, Venezia: p. 145-155. (in Italian) ("Venetian and Raetic People")

Marzatico, F. 2014, Lungo le vie dell'Est: scambi culturali fra Reti, Veneti e popolazioni dell'area sudalpina orientale. In: Transalpinare. Mélanges offerts à Anne-Marie Adam (Alberti, G., Féliu, C., \& Pierrevelcin G., Eds.), Ausonius Editions Mémoires Vol. 36, Ausonius Ed., Bordeaux: p. 403-422. (in Italian) (“Along the East Roads: Cultural Exchanges between Raetian, Venetian and Populations of the Eastern South-Alpine region")

Morandi, A. 1999, Il cippo di Castelciès nell'epigrafia retica, Studia archaeologica Vol. 103. L'Erma di Bretschneider, Roma, 114 p. (in Italian) ("The Stone of Castelciès in the Raetic Epigraphy”)

Morrone, V. 1999, Le macine a tramoggia di Monte Bibele. OCNUS, 7: 69-78. (in Italian) (“The Hopper Rubbers from Monte Bibele”)

Nascimbene, A. 2009, Le alpi orientali nell'età del Ferro (VII-V secolo a.C.), L'album Vol. 15. Fondazione Antonio Colluto, Portogruaro (Venice), 324 p. (in Italian) ("The Eastern Alps in Iron Age ( $7^{\text {th }}-5^{\text {th }}$ cent. BCE)") 
De Pantz, G. 1892, S. Donato di Lamon - Tomba di età imperiale scoperta nella parte bassa del paese. Notizie degli Scavi di Antichità: 38. (in Italian) ("San Donato in the Municipality of Lamon - Imperial Age Burial Discovered in the Lower Part of the Village”)

Pasquali, T., (Ed.) 2010, I castellieri preistorici del Trentino. Attraverso le ricerche di Desiderio Reich e Carl Ausserer. L'alta Valsugana - Aggiornamenti. Publistampa, Pergine Valsugana, Trento, 351 p. (in Italian) ("Prehistoric "castellieri” in Trentino. Through the Research of Desiderio Reich and Carl Ausserer. The High Valsugana Updates")

Peacock, D.P.S. 2013, The stone of life. The archaeology of querns, mills and flour production in Europe up to c. AD 500, Southampton monographs in archaeology. New series Vol. 1. Highfield Press Southampton, Southampton, 220 p.

Perini, R. 1978, 2000 anni di vita sui Montesei di Serso. Grafiche Istituto Artigianelli, Trento, 85 p. (in Italian) ("2000 Years of Life on the Montesei di Serso")

Piatti, S. 1998, Pergine. Un viaggio nella sua storia. Publistampa, Pergine Valsugana, Trento, 1026 p. (in Italian) ("Pergine. A Trip in its History")

Pliny the Elder, 77-79, Naturalis Historia, Vol. 1, (Barchiesi, A., Centi, R., Corsaro, M., Marcone, A. \& Ranucci, G., Eds., 1982 edition), Einaudi, Bologna, 847 p.

Dal Ri, L. 1987, Influssi etrusco-italici nella regione retico-alpina. In: Gli etruschi a nord del Po, Vol. 1 (De Marinis, R., Ed.), Campanotto, Udine: p. 160-179. (in Italian) (“The Etruscans north of the Po")

Dal Ri, L. 1991, Macine per cereali dell'Età del Ferro e di epoca romana della Val di Fiemme. In: La val di Fiemme nel Trentino. Dalla preistoria all'alto Medioevo (Leonardi, P., Ed.), Manfrini, Calliano, Trento: p. 433-445. (in Italian) ("Iron Age and Roman Grain Millstones in the Fiemme Valley")

Dal Ri, L. 1992, Etruskische Einflüsse im Etschtal. In: Etrusker nördlich von Etrurien. Etruskische Präsenz in Norditalien und nördlich der Alpen sowie ihre Einflüsse auf die einheimischen Kulturen. Akten des Symposions (Oktober 2 -5 1989, Wien) (AignerForesti, L., Ed.), Sitzungsberichte Vol. 589, Österreichischen Akademie der Wissenschaften, Wien: p. 71-91. (in German) (“Etruscan Influences in Adige Valley”)

Rigoni, A.N. 1990, Castelciés di Cavaso del Tomba: saggi di scavo nella chiesetta di S. Martino. Quaderni di Archeologia del Veneto, 6: 117-134. (in Italian) ("Castelciés in the Municipality of Cavaso del Tomba: Archaeological Excavations in Saint Martin Church”)

Rigoni, A.N. 1991, Cavaso del Tomba. Saggi di scavo a Castelciés. Quaderni di Archeologia del Veneto, 7: 42-58. (in Italian) ("Cavaso del Tomba. Archaeological Excavations at Castelciés”)

Rigoni, A.N. 1993, Castelciés (Cavaso del Tomba). Lo scavo di una fortificazione medievale. Quaderni di Archeologia del Veneto, 9: 53-64. (in Italian) ("Castelciés (Municipality of Cavaso del Tomba). The Excavations of a Medieval Fortress”)

Rigoni, A.N. 2004, San Martino di Castelciés e i segni della storia, Acculeia zosime Vol. 6. Zanetti, Caerano San Marco, Treviso, 120 p. (in Italian) ("San Martino at Castelciés and the Signs of the History") 
Rigoni, M., \& Maggiani, A. 2002, Due frammenti di iscrizione. In: Akeo. I tempi della scrittura. Veneti antichi. Alfabeti e documenti, Museo di storia naturale e archeologia di Montebelluna, Cornuda, Treviso: p. 184-185, n. 18. (in Italian) ("Two Fragments of Inscriptions”)

Sassatelli, G. 1993, La funzione economica e produttiva: merci, scambi, artigianato. In: Spina. Storia di una città tra Greci ed Etruschi (Berti, F., \& Guzzo, P.G., Eds.), Ferrara Arte, Ferrara: p. 179-217. (in Italian) (“The Economic and Productive Role: Goods, Exchanges, Craftsmanship”)

Sassatelli, G. 1999, Nuovi dati epigrafici e il ruolo degli Etruschi nei rapporti con l'Italia nord-orientale. In: Protostoria e storia del "Venetorum Angulus". Atti del XX Convegno di studi etruschi ed italici (October 16-19 1996, Portogruaro-Quarto d'Altino-EsteAdria) (Paoletti, O., Ed.), Istituti editoriali e poligrafici internazionali, Pisa-Roma: p. 451-474. (in Italian) ("New Epigraphic Data and the Role of the Etruscans in the Relationships with North-Eastern Italy”)

Šedo, O. 2004, Mlecí kameň gréckeho typu zo Žiliny-Závodia a problémy kontaktov stredomoria s priestorom Hércynského lesa / Ein Mahlstein griechischen Typs aus Žilina-Závodie und Probleme der Kontakte des Mittelmeerraums mit dem Raum des Herzynischen Waldes. Studijne Zvesti, 36: 7-14. (in Slovak) (“A Greek Type Millstone from Zilina-Závodia and the Problems of Contacts between the Mediterranean Regions and the Area of Hércyn Forest”)

Tiziani, P. 1900, Memorie e indagini storiche lamonesi. Handwritten notebook, Feltre Public Library, 41 p. (unpublished) (in Italian) ("Historical Memories and Investigations about Lamon”) 


\title{
La macina "tipo Olinto" nelle Alpi: nuove ipotesi da due esemplari non ancora identificati, scoperti nella regione Veneto (Italia)
}

\author{
Denis Francisci \\ Dipartimento dei Beni culturali, Università di Padova, Italia. Email: denis.francisci@gmail.com
}

\section{Riassunto (Italiano):}

Il museo di Feltre (Provincia di Belluno, Regione Veneto, Italia) conserva nella sua collezione archeologica i frammenti di due antiche macine di pietra del tipo noto come "Olynthus mill” o "hopper rubber”. La prima (da San Donato di Lamón, in provincia di Belluno) è citata in alcune opere edite e inedite; l'altra (genericamente da Feltre) è nuova alla letteratura archeologica. Fino ad ora, non erano mai state identificate come esemplari di macine tipo Olinto.

Dopo una breve introduzione su questo tipo di strumento (caratteristiche tecniche, origine e distribuzione geografica) e sulle ipotesi principali relative alla sua diffusione nelle Alpi, la prima parte di questo contributo è dedicata alla descrizione delle due pietre di Feltre: dimensioni, caratteristiche morfologiche, materia prima, ecc. Nelle parti seguenti, l'attenzione sarà focalizzata sui siti dove furono scoperte le due macine e sulla loro importanza per comprendere la diffusione di questo modello di strumento nella regione alpina caratterizzata dalla cultura retica, problema quest'ultimo ancora irrisolto. I luoghi di provenienza di questi due reperti molitori (insieme ai siti di ritrovamento delle altre macine a tramoggia e leva presenti nella Regione Veneto e nella parte orientale della Provincia di Trento) potrebbero suggerire, infatti, nuove ipotesi di lavoro sulla provenienza di questo tipo di macina e sul modo in cui essa venne introdotta nel territorio retico tra il V e il IV secolo a.C. In particolare, la via di ingresso del modello della macina olintica nelle Alpi potrebbe corrispondere alle valli del Piave e del Brenta e non alla valle dell'Adige come finora sostenuto; le macine di tipo olintico del Veneto potrebbero marcare le tappe di questo percorso da sud verso nord e non rappresentare semplicemente esemplari periferici dell'area retica o beni da là esportati.

Keywords: Macina “tipo Olinto”; Hopper Rubber; macine protostoriche; Reti; seconda Età del Ferro; Veneto 